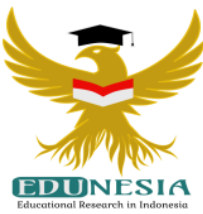

\title{
Minat Baca Siswa Ditinjau Dari Persepsi Keterlibatan Orangtua Dalam Pendidikan
}

\author{
Roy Gustaf Tupen Ama \\ Psikologi, Universitas Mercu Buana Yogyakarta, Indonesia \\ Corresponding Email: Royama27@gmail.com, Phone Number : 0821 xxxx xxxx
}

\author{
Article History: \\ Received: Dec 07, 2020 \\ Revised: Dec 08, 2020 \\ Accepted: Dec 10, 2020 \\ Published: Jan 01, 2021
}

Keywords:

Reading interest, perceptions of parental involvement

Kata Kunci:

Minat baca, persepsi

keterlibatan orangtua

\begin{tabular}{l}
\hline How to cite: \\
Ama, R.G.T. \\
Baca Siswa Ditinjau Dari \\
Persepsiratran \\
Orangtua Dalam Pendidikan. \\
Edunesia: Jurnal Ilmiah \\
Pendidikan, 2 (1): 219-229.
\end{tabular}

This is an open access article under the $C C-B Y-N C-N D$ license (c) (1) $\odot$
Abstract: Reading interest is very important to grow from an early age in elementary school because with reading interest students will get a lot of knowledge from reading. This study aimed to determine the correlations between between perceptions of parental involvement in education and students reading interest. The research method used is a quantitative correlation approach. In this study, the researcher used some scales, namely scale of perceptions of parental involvement in education, and scale of students' interest in reading. The population of this study was all third, fourth, and fifth grade students of Triharjo State Elementary School in Sleman, with a total sample of 124 students. The sampling technique used was purposive sampling with a sample size of 124 students with the sample criteria, namely students in grade 3,4 and 5, male and female and live with their parents. To analyze the hypothesis the Product Moment correlation technique was used. The results of the analysis show that there is a correlation between perceptions of parents' involvement and students' reading interest with an $r$ value of 0.697 . The results of this study indicate that students' reading interest is in the medium category, it is obtained from the classification results for the medium category as much as $80.6 \%$, and students have a high perception of parental involvement in education as much as $51.6 \%$.

Abstrak: Minat baca merupakan hal penting penting untuk di tumbuhkan sejak dini khususnya pada siswa sekolah dasar, karena dengan adanya minat baca siswa-siswi akan mendapat banyak pengetahuan dari membaca. Penelitian ini bertujuan untuk mengetahui hubungan antara persepsi keterlibatan orangtua dalam pendidikan dengan minat baca siswa. Metode penelitian yang digunakan yaitu pendekatan kuantitatif korelasional. Dalam penelitian ini, peneliti menggunakan skala yaitu skala minat baca dan skala persepsi keterlibatan orangtua dalam pendidikan. Populasi dalam penelitian ini adalah seluruh siswa kelas 3,4, dan 5 di SDN Triharjo Sleman. Teknik pengambilan sampel yang digunakan adalah purposive sampling dengan jumlah sampel adalah 124 siswa dengan kriteria sampel yaitu siswa kelas 3, 4 dan 5, laki-laki dan peremuan serta tinggal bersama orangtua. Teknik analisis dalam penelitian ini menggunakan teknik korelasi product moment. Hasil analisis menunjukkan bahwa ada hubungan antara persepsi keterlibatan orangtua dalam pendidikan dengan minat baca siswa, nilai $r=0,697$. Hasil penelitian ini menunjukkan bawa minat baca siswa berada pada kategori sedang sebanyak 80,6\%, dan siswa memiliki persepsi keterlibatan orangtua dalam pendidikan yang tinggi sebanyak $51,6 \%$. 


\section{A. Pendahuluan}

Seiring dengan perkembangan IPTEK pada Era milenial, maka berbagai cara dan strategi terus dilakukan untuk meningkatkan kualitas pendidikan, karena pendidikan selalu mengalami perkembangan dari tahun ke tahun atau dari masa ke masa. Pendidikan juga merupakan instrumen yang sangat luas dan sangat penting, dalam pendidikan tersebut memuat pengetahuan dan nilai -nilai yang terkandung di dalamnya (Surya, 2013). Pendidikan tidak terlepas dari proses belajar. Salah satu cara belajar yang baik yaitu dengan membaca.

Menurut Badan Pusat Statistik Indonesia (BPS), survei yang dilakukan pada tahun 2015 menunjukkan bahwa 91,47\% anak usia sekolah lebih suka menonton televisi dan $13,11 \%$ anak usia sekolah yang lebih suka membaca (Kementerian Pendidikan dan Kebudayaan, 2018). Secara umum, berdasarkan data dari Badan Pusat Statistik tahun 2012 menujukkan bahwa sebanyak 91,58 persen masyarakat Indonesia yang berusia 10 tahun ke atas lebih suka menonton televisi dan hanya sekitar 17,58 persen saja masyarakat yang gemar membaca buku, surat kabar, atau majalah.

Kemajuan teknologi informasi dan komunikasi telah menjadi penghalang minat anak-anak dalam membaca. Media digital saat ini telah berhasil menjadi pengalih perhatian bagi anak-anak Indonesia saat ini. Hal itu bisa dilihat dari kegiatan sehari-hari mereka yang lebih sering dihabiskan di depan televisi dan gadget karena media lebih menarik bagi mereka (Yaumi, 2014). Melihat situasi ini seharusnya menjadi perhatian khusus bagi semua pelajar dan yang terlibat dalam proses pendidikan dalam meningkatkan kualitas dan kecakapan dalam belajar. Kualitas dan kecakapan belajar dapat ditingkatkan dengan cara meluangkan waktu untuk membaca. Sehingga jika terus dilakuksan akan membiasakan diri dan menciptakan minat dalam membaca.

Susilowati (2016) menjelaskan bahwa membaca adalah keterampilan yang harus dimiliki oleh semua praktisi pendidikan. Membaca merupakan kunci dasar yang harus dilakukan oleh seorang pelajar jika dia ingin meraih prestasi dalam belajar, karena dengan membaca akan menambah wawasan serta ilmu pengetahuan. Selain itu membaca akan menjadikan individu yang berkualitas. Bagi seorang pelajar dengan membaca akan memudahkan untuk mencapai prestasinya. Tidak semua pelajar akan mudah memahami apa yang dibacanya. Salah satu faktor yang harus dimiliki seorang pelajar ketika membaca yaitu minat. Minat berhubungan dengan perasaan senang terhadap sesuatu, sehingga minat akan mendorong seseorang untuk melakukan apa yang diinginkannya (Hurlock, 2013). Hal ini disebabkan adanya ketertarikan dari dalam diri seseorang terhadap suatu hal yang ia pelajari.

Minat baca diartikan sebagai sebuah aktivitas dalam bentuk dorongan dalam diri individu dalam memahami kata demi kata dan isi dari sebuah bacaan, dengan penuh ketekunan, kesadaan dan rasa senang (Dalman, 2013). Mansyur (2018) memberikan pengertian bahwa minat baca adalah intensitas kesenangan yang kuat karena adanya dorongan yang timbul pada diri seseorang dalam melakukan aktivtas membaca untuk memperoleh informasi, serta menimbulkan kesenangan dan manfaat bagi dirinya. Sudarsana (2014) menambahkan bahwa pengetian minat baca adalah aktivitas yang dilakukan dengan penuh ketekunan dan cenderung menetap dalam rangka membangun pola komunikasi dengan diri sendiri agar pembaca dapat menemukan makna tulisan dan memperoleh informasi sebagai proses transmisi pemikiran untuk mengembangkan intelektualitas dan pembelajaran sepanjang hayat (life-long learning) serta dilakukan dengan penuh kesadaran dan mendatangkan perasaan senang, suka, dan gembira. Minat 
baca yang tinggi pada siswa akan nampak dari seberapa besar siswa memiliki kesadaran akan manfaat membaca, siswa memiliki perhatian terhadap membaca, siswa menunjukkan rasa senang dalam membaca dan seberasa sering siswa melakukan kegiatan membaca atau yang disebut frekuanesi dalam membaca. Harris dan Sippay (Nursalina, 2014).

Survei yang dilakukan oleh Central Connecticut State University mengenai budaya literasi menempatkan Indonesia pada urutan ke-60 dari 61 negera yang disurvei, Indonesia hanya berada setingkat lebih baik dari Bostwana. Adapun hasil survei tersebut menempatkan negara seperti, Finlandia, Norwegia, Islandia, Denmark, dan Swedia sebagai lima negara dengan tingkat budaya literasi terbaik di dunia (Central Connecticut State University, 2016). Hasil ini juga menunjukkan bahwa minat membaca buku pada masyarakat Indonesia sangat rendah bila dibandingkan dengan negara berkembang lainnya. Hal ini sejalan dengan studi yang dilakukan oleh Rachman dan Rachmawati (2017) mengenai studi kasus minat baca pada siswa sekolah dasar menghasilkan bahwa minat baca siswa kelas 3 Sekolah Dasar Negeri Anyelir 1 Depok tergolong masih rendah, hal ini terlihat dari hasil survei yang dilakukan kepada seluruh siswa kelas 3 dengan jumlah sampel 154 menunjukkan secara keseluruhan tidak lebih dari 55\% siswa yang melakukan kegiatan membaca. Namun demikian, 55\% siswa menyatakan bahwa membaca merupakan kegiatan yang telah dilaksanakan secara rutin sejak dulu. Rendahnya minat baca tersebut dikarenakan kesadaran membaca, kesenangan membaca dan kebiasaan membaca yang rendah.

Hal di atas sejalan dengan hasil wawancara dan observasi pada tanggal 04 oktober 2019 di SDN Triharjo Sleman pada kelas 3, 4 dan 5 bahwa siswa/i memiliki minat baca yang tergolong rendah yaitu tidak memiliki kesadaran sendiri dalam membaca buku, perhatian yang rendah dalam membaca buku baik disekolah apalagi di rumah, tidak menunjukan kesenangan saat membaca buku dan frekuensi membaca buku yang rendah karena jarang membaca buku baik di Sekolah dan di rumah. Selanjutnya temuan berikutnya saat melakukan wawancara dengan guru bahwa bahwa rendahnya minat baca siswa/I SDN Triharjo karena kurangnya keterlibatan orangtua dalam pendidikan anak.

Menurut Dalman (2013), bahwa faktor-faktor yang mempengaruhi minat baca yaitu faktor lingkungan keluarga, faktor fasilitas sekolah, faktor kurikulum sekolah dan faktor keberadaan dan kejangkauan bahan bacaan. Selanjutnya faktor yang mempengaruhi minat baca yang dipilih dalam penelitian ini yaitu faktor lingkungan keluarga dengan berfokus pada peran atau keterlibatan orang tua. Keterlibatan orang tua dipilih sebagai faktor yang mempengaruhi minat baca dalam penelitian karena berdasarkan temuan di lapangan yang telah dijelaskan sebelumnya bahwa pihak sekolah mengharapkan orang tua berperan dan terlibat dalam menumbuhkan minat baca. Guru mengeluhkan bahwa sejauh ini, masih kurangnya peran dari orang tua siswa/i dalam kegiatan belajar terutama membiasakan budaya membaca di rumah. Hornby (2011) mendefinisikan keterlibatan orang tua dalam pendidikan adalah bentuk partisipasi orang tua dalam proses dan pengalaman pendidikan anak-anak mereka. Robinson dan Haris (2014) mendefenisikan keterlibatan orangtua dalam pendidikan adalah bentuk partisipasi orangtua terhadap anak dengan melakukan proses komunikasi yang berkaitan dengan proses belajar dengan anak, memberikan kepercayaan dan menunjukkan perilaku serta strategi dalam proses belajar. Epstein (2011) berpendapat bahwa keterlibatan orang tua dalam pendidikan adalah sebuah bentuk tanggung jawab orang tua terhadap anaknya dirumah, di sekolah maupun di masyarakat yang diwujudkan dalam bentuk kerjasama, 
berbagi informasi, membimbing, memecahkan masalah dan meraih keberhasilan. Bentuk bentuk keterlibatan orangtua dalam pendidikan menurut Hill dan Tyon (2009) terdiri dari 3 (tiga) yaitu home-base involvement (keterlibatan di rumah), school-base involvement (keterlibatan di sekolah), dan academik socialization (sosialisasi akademik), bentuk-bentuk keterlibatan orangtua inilah yang akan digunakan sebagai konstrak teori dalam mengukur persepsi keterlibatan orangtua dalam pendidikan.

Minat baca memiliki hubungan dengan variabel lainnya. Salah satunya minat baca berkorelasi dengan Persepsi keterlibatan orang tua. Penelitian yang dilakukan oleh Rahmi (2019) mengenai keterlibatan orang tua dalam meningkatkan minat baca pada anak menghasilkan bahwa keterlibatan orang tua memiliki hubungan yang positif dan signifikan terhadap minat baca pada anak bahwa jika orang tua terlibat secara positif dalam proses membaca pada anak maka minat baca anak akan menjadi tinggi. Penelitian yang dilakukan oleh Arumdini, Winoto dan Anwar (2016) mengenai peran orang tua dalam hal pola asuh dengan minat baca menghasilkan bahwa besarnya peran yang ditunjukkan oleh orang tua yang merupakan bagian dari pola asuh dapat meningkatkan minat baca siswa. Penelitian yang dilakukan Shohibah (2017) mengenai peran orang tua dalam mengembangkan budaya literasi pada anak usia sekolah dasar menghasilkan bahwa peran atau keterlibatan orangtua sangat penting dalam menumbuhkan minat baca. Berdasarkan penjelasan diatas maka peneliti mengajukan hipotesis sebagai berikut: "Ada hubungan positif antara pesepsi keterlibatan orangtua dalam pendidikan dengan minat baca siswa".

\section{B. Metode}

Penelitian ini terdiri dari 2 variabal sebagai berikut:

1. Minat Baca

Minat baca didefenisikan sebagai keinginan kuat yang timbul dari dalam diri individu disertai dengan usaha-usaha yang dilakukan oleh individu dalam proses membaca. Minat baca diungkap dengan menggunkan skala minat baca yang mengacu pada teori harris dan sippay (Nursalina, 2014) yaitu : kesadaran akan manfaat membaca yaitu subyek menyadari, mengetahui dan memahami akan pentingnya manfaat membaca, perhatian terhadap membaca buku yaitu mengungkap perhatian dan ketertarikan yang tinggi dalam membaca buku, rasa senang yaitu aspek yang mengungkap seberapa besar subjek menunjukkan rasa senang yang tinggi terhadap aktivitas membaca baik di sekolah maupun di rumah dan frekuensi membaca aspek yang mengungkap seberapa sering subyek melakukan aktivitas atau kegiatan membaca buku.

2. Persepsi Keterlibatan Orangtua Dalam Pendidikan

Persepsi terhadap keterlibatan orang tua dalam pendidikan merupakan penilaian siswa terhadap keterlibatan orang tua dalam pendidikan yang melibatkan proses interaksi orang tua dengan pihak sekolah dan interaksi orang tua dengan siswa di rumah dalam rangka mencapai kesuksesan akademik. Persepsi keterlibatan orangtua dalam pendidikan diuangkap dengan menggunakan skala persepsi keterlibatan orangtua dengan mengacu pada teori Hill dan Tyson (2009) yaitu : home-based involvement (keterlibatan dirumah), school-based involvement (keterlibatan di sekolah) dan academik socialization (sosialisasi akademik).

Skala minat baca dan persepsi keterlibatan orangtua dalam pendidikan diuji cobakan pada 74 siswa kelas 3, 4, dan 5 di SDN " $X$ " di Yogyakata. Hasil dari pengujian 
nilai validitas dan reliabilitas pada Skala minat baca menghasilkan 31 item yang valid dari 32 item yang diujicobakan. Koefisien validitas bergerak antara 0,322 sampai dengan 0,732 sedangkan untuk pengujian reliabilitas menggunakan reliabilitas alpha, menunjukkan koefisien reliabilitas sebesar 0,927 . Selanjutnya hasil dari pengujian terhadap validitas dan reliabilitas skala persepsi keterlibatan orangtua dalam pendidikan menghasilkan 37 item yang valid dari 48 item yang diujicobakan. Koefisien validitas bergerak antara 0,311 sampai dengan 0,695, sedangkan untuk pengujian reliabilitas menggunakan reliabilitas alpha, menunjukkan koefisien reliabilitas sebesar 0,919.

Populasi dalam penelitian ini adalah seluruh kelas Kelas 3, 4 dan 5 berjumlah 180 siswa/i SDN Triharjo Sleman. Adapun cara dalam penentuan sampel, penulis menggunakan non random sampling, yaitu teknik purposive sampling. Beberapa pertimbangan dalam pengambilan sampel yaitu berdasarkan pengamatan dilapangan sebelumnya pada saat observasi dan wawancara awal terhadap siswa/I kelas 3, 4 dan 5 yang sudah lancar membaca dan tinggal bersama orangtua serta pertimbangan khusus dari peneliti adalah karena penelitian ini dilaksanakan di masa pademi COVID-19, sehingga proses pngambilan sampel menggunakan google doc. Pengujian hubungan antara satu variabel independen dengan satu variabel dependen (persepsi keterlibatan orangtua dalam pendidikan dengan minat baca pada siswa) menggunakan metode analisis data yaitu korelasi pearson product moment.

\section{Hasil dan Pembahasan}

Sebelum dilakukan uji Korelasi maka di lakukan uji prasyarat terlebih dahulu yang terdiri dari uji normalitas dan linieritas sebagai berikut:

\section{Uji Normalitas}

Data penelitian ini diuji menggunakan uji Kolmogorov Smirnov. Hasil uji normalitas variabel minat baca dan persepsi keterlibatan orangtua dalam pendidikan dapat dilihat pada tabel di bawah ini.

Tabel 1. Hasil Uji Normalitas Minat Baca dan Persepsi Keterlibatan Orangtua dalam Pendidikan

\begin{tabular}{|lcccc|}
\hline \multicolumn{1}{c}{ Variabel } & $\begin{array}{c}\text { Kolmogorov- } \\
\text { Smirnov } \mathbf{Z}\end{array}$ & $\mathbf{P}$ & Subjek & Keterangan \\
\hline Minat Baca & 1,240 & 0,092 & 124 & Normal \\
\hline $\begin{array}{l}\text { Perepsi keterlibatan } \\
\text { orangtua }\end{array}$ & 1,320 & 0,067 & 124 & Normal \\
\hline
\end{tabular}

Sumber: data primer diolah (2020)

Berdasarkan hasil uji normalitas yang telah dilakukan, maka didapatkan hasil bahwa :

1. Uji normalitas minat baca nilai KSZ sebesar 1,240 dan nilai $p$ sebesar $0,092(p>0,05)$. Hal tersebut menunjukkan bahwa variabel minat baca pada siswa memiliki sebaran normal. 
2. Uji normalitas data persepsi keterlibatan orang tua dalam pendidikan didapatkan nilai KSZ sebesar 1,320 dan nilai $p$ sebesar 0,067 ( $>>0,05$ ). Hal tersebut menunjukkan bahwa variabel persepsi keterlibatan orang tua pada siswa memiliki sebaran normal.

\section{Uji Linieritas}

Hasil uji linieritas dapat dilihat pada tabel dibawah ini:

Tabel 2.

Hasil Uji Linieritas Variabel Minat Baca dan Persepsi Keterlibatan Orangtua dalam Pendidikan

\begin{tabular}{|c|c|c|c|c|}
\hline \multirow{2}{*}{$\begin{array}{c}\text { Variabel } \\
\text { Dependen }\end{array}$} & \multirow{2}{*}{$\begin{array}{c}\text { Variabel } \\
\text { Independen }\end{array}$} & \multicolumn{2}{|c|}{ Nilai } & \multirow{2}{*}{ Keterangan } \\
\hline & & $\mathbf{F}$ & $p$ & \\
\hline Minat Baca & $\begin{array}{l}\text { Persepsi Keterlibatan } \\
\text { Orang tua }\end{array}$ & 123,821 & 0,000 & Linier \\
\hline
\end{tabular}

Sumber: data primer diolah (2020)

Berdasarkan hasil uji linieritas pada tabel 2 di atas menunjukkan bahwa variabel persepsi keterlibatan orangtua dalam pendidikan dengan nilai $\mathrm{F}$ sebesar 123,821 dengan signifikansi pada linierity $(\mathrm{p}<0,05)$, sehingga dapat disimpulkan bahwa antara variabel persepsi keterlibatan orangtua dan minat baca terdapat hubungan yang linier.

\section{Uji Korelasi}

Hasil analisis korelasi pearson product moment dapat dilihat pada tabel berikut;

Tabel 3. Uji korelasi variabel independen dengan minat baca

\begin{tabular}{cccc}
\hline $\begin{array}{c}\text { Variabel } \\
\text { Independen }\end{array}$ & $\begin{array}{c}\text { Koefisien } \\
\text { Korelasi } \\
\left(\mathbf{r}_{\mathbf{x y}}\right)\end{array}$ & $\begin{array}{c}\text { Sig }(\mathbf{2} \\
\text { tailed) }\end{array}$ & Ket. \\
\hline $\mathrm{X} 1$ & 0,697 & 0,000 & Sig. \\
\hline
\end{tabular}

Sumber : Data Primer diolah (2020)

Berdasarkan tabel 1. diatas diketahui bahwa Variabel persepsi keterlibatan orangtua dalam pendidikan mempunyai hubungan yang positif dan signifikan terhadap motivasi belajar siswa $(\mathrm{p}<0,000)$. Hal tersebut menunjukkan bahwa hipotesis yang diajukan dalam penelitian ini diterima. Besarnya nilai $r=0,697$, apabila dikuadradkan $\left(r^{2}\right)$ menjadi 0,461. Koefisien determinasi $\left(\mathrm{r}^{2}\right)$ sebesar 0,461 yang berarti bahwa sumbangan efektif yang diberikan persepsi keterlibatan orangtua dalam pendidikan terhadap minat baca siswa $46,1 \%$ sedangkan $53,9 \%$ dipengaruhi oleh faktor lain.

\section{Kategorisasi Data}

Selanjutnya Peneliti melakukan kategorisasi data pada skala minat baca, skala persepsi keterlibatan orangtua dalam pendidikan untuk mendapatkan informasi mengenai keadaan subjek secara lebih mendalam. Cara ini dilakukan berdasarkan asumsi bahwa skor subjek dalam kelompoknya merupakan estimasi terhadap skor subjek. 
Kategori yang ditetapkan untuk masing-masing skala adalah tinggi, sedang dan rendah (Azwar, 2017). Hasil kategorisasi diuraikan sebagai berikut.

Tabel 4. Kategorisasi Skor Skala Minat Baca

\begin{tabular}{clccc}
\hline Variabel & Kategori & Interval Skor & Jumlah & Persentase \\
\hline Minat Baca & Rendah & $x<77,5$ & 8 & 6,5 \\
& Sedang & $77,5 \leq x<108.5$ & 100 & 80,6 \\
& Tinggi & $x \geq 108,5$ & 16 & 12,9 \\
\hline & Total & 124 & 100,0 \\
\hline
\end{tabular}

Sumber: data primer diolah (2020)

Berdasarkan Tabel 2. diketahui bahwa siswa yang memiliki minat baca kategori rendah sebanyak 8 orang (6,5\%), kategori sedang sebesar 80,6\% (100 orang) dan kategori tinggi sebesar 12,9 \% (16 orang). Dapat disimpulkan bahwa variabel minat baca siswa adalah sedang.

Tabel 5.

Kategorisasi Skor Skala Persepsi Keterlibatan Orangtua dalam Pendidikan

\begin{tabular}{llccc}
\hline \multicolumn{1}{c}{ Variabel } & Kategori & Interval Skor & Jumlah & Persentase \\
\hline Persepsi & Rendah & $x<67,84$ & 0 & 0,0 \\
Keterlibatan & Sedang & $67.84 \leq x<117,16$ & 60 & 48,4 \\
orangtua & Tinggi & $x \geq 117,16$ & 64 & 51,6 \\
\hline \multicolumn{5}{c}{ Total } \\
\hline
\end{tabular}

Sumber: data primer diolah (2020)

Berdasarkan Tabel 3, diketahui bahwa siswa yang mendapatkan persepsi keterlibatan orang tua dalam pendidikan kategori rendah sebanyak 0 orang $(0,0 \%)$, kategori sedang sebesar 48,4\% (60 orang) dan kategori tinggi sebesar 51,6\% ( 64 orang). Dapat disimpulkan bahwa variabel persepsi keterlibatan orangtua dalam pendidikan adalah tinggi.

\section{Pembahasan}

Hasil pengujian data dengan menggunakan teknik analisis korelasi product moment menunjukkan bahwa nilai korelasi yang didapat sebesar $0,697(p<0,01)$. Hasil analisis data telah membuktikan hipotesis dalam penelitian ini yang menunjukkan adanya hubungan yang positif dan signifikan antara persepsi keterlibatan orangtua dalam pendidikan dengan minat baca siswa. Siswa/i SDN Triharjo yang memiliki pesepsi positif tentang keterlibatan orangtua dalam pendidikan maka semakin tinggi pula minat baca, demikian pula sebaliknya semakin negatif persepsi siswa keterlibatan orangtua dalam pendidikan akan semakin rendah pula minat baca siswa. Minat baca siswa dapat terwujud karena adanya peran dari keterlibatan orangtua dalam pendidikan.

Keterlibatan orangtua dalam pendidikan dalam hal keterlibatan dirumah turut dirasakan dan dinilai positif oleh siswa/I SDN Triharjo, seperti berkomunikasi dengan 
anak mengenai aktivitas belajar di sekolah, mendampingi anak belajar di rumah, menciptakan lingkungan belajar yang nyaman, menyediakan buku-buku bacaan dalam belajar. Proses membentuk kebiasaan membaca diperlukan keterlibatan orang tua baik dirumah. Ketika anak-anak menganggap model (orangtua) memiliki keterampilan dan kemampuan membaca, hal ini akan memberikan dampak baik yang signifikan dan kuat untuk anak dalam membangun kesadaran dalam membaca (Bandura, 2011). Sehingga, dapat disimpulkan bahwa orang tua memiliki peran untuk terlibat di rumah dalam dalam mendampingi anak belajar khususnya mencontohkan kegiatan membaca, yang akan diikuti pula oleh anak-anak dan hal tersebut dapat meningkatkan minat baca pada anak.

Hal ini dijelaskan oleh hasil penelitian dari Rahmawati dan Arnomo (2016) bahwa dalam rangka menumbuhkan minat baca pada anak memiliki berbagai macam keterlibatan yang bervariasi. Orangtua dapat menumbuhkan minat membaca pada anak misalnya dengan melakukan aktivitas membaca di depan anak-anak, mendongengi anak, mengajak anak bermain tebak kata, memperkenalkan huruf-huruf kepada anak, mengajari anak mengeja dan atau membaca, mengajak anak ke toko buku dan membiarkan anak memilih buku yang disukainya dan mengajak anak ke perpustakaan. Sehingga perlibatan orang tua dalam pendidikan diatas bisa diterapkan bagi orangtua wali murid siswa/I SDN Triharjo guna menghasilkan hasil belajar yang baik khususnya dalam proses menumbuhkan minat baca bagi siswa/i.

Selain keterlibatan di rumah, orangtua juga perlu dan penting untuk terlibat dalam kegiatan di sekolah, untuk mengetahui sejauhmana perkembangan belajar anak dalam bentuk evaluasi-evaluasi belajar yang diberikan guru ke orangtua (Epstein, 2011). Hal ini pun yang juga dirasakan oleh siswa/I SDN Triharjo bawasannya mereka merasakan bahwa sejauh ini orang tua telah andil terlibat di sekolah berdasarkan hasil penelitian ini. Schunk (2010) menjelaskan bahwa keterlibatan orang tua dalam pendidikan ditunjukkan dengan terlibat di sekolah seperti mengunjungi siswa saat di sekolah, mengikuti pertemuan rutin dengan guru, ikut serta dalam kegiatan- kegiatan siswa. Dengan kehadiran orang tua dalam partisipasi di sekolah membuat siswa/i SDN Triharjo merasa orang tuanya terlibat dalam proses pembelajaran di sekolah dan meningkatkan semangat belajar siswa.

Selanjutnya academic socialization (sosialisasi akademik) berupa Strategi yang dilakukan orang tua untuk membuat anak lebih mandiri, berkembang kognitifnya dalam proses belajar sehingga anak sadar akan mafaat belajar juga dirasakan dan dipersepsi positif oleh siswa/i SDN Triharjo Sleman. Hill dan Tyson (2009) menjelaskan bahwa pentinya orangtua menyiapkan masa depan anak sejak awal saat anak bersekolah, karena hal ini adalah bentuk yang continue sampai anak meraih keberhasilan akademik dalam belajar dan dalam menggapai cita-citanya kedepan. Kegiatan-kegiatan yang dapat dilakukan adalah orangtua mensosialisasikan informasi-informasi terbaru seputar pengetahuan, orangtua menyiapkan stategi belajar dengan nenawarkan anak untuk ikut kegiatan les tambahan atau kursus dalam menunjang bakat dan minat dalam belajar, serta orangtua mengarahkan anak untuk bisa mencapai target-target akademik dalam proses belajar sehinga anak menjadi untuk rajin belajar dan membaca buku agar berhasil dan sukses dalam akademik dan dimasa yang akan datang. Hornby (2011) menambahkan bahwa kesuskesan akademik yang dicapai anak dipengaruhi oleh seberapa besar orangtua mengarahkan anak, orangtua memberikan informasi-informasi positif tekait belajar (misalnya seminar, lomba, turnamen, kurus dan ektrakurikuler), orangtua menjelaskan 
pentingnya belajar serta orangtua membantu anak dalam hal strategi yang nyata dan kongkrit agar anak mampu berhasil dan bersaing dalam akademik disekolah.

Keterlibatan orang tua dalam pendidikan memiliki hubungan dengan minat baca pada siswa. Dalam hal ini persepsi siswa memainkan peran penting dalam mempersepsikan ketelibatan orang tua dalam kegiatan membaca. Hal ini dibuktikan melalui penelitian yang dilakukan oleh Fakhriyah (2018) bahwa ada hubungan postif antara pesepsi keterlibatan orang tua dengan minat baca siswa sekolah dasar. Senada dengan penelitian diatas, penelitian yang dilakuakan oleh Kitmachi (2014) dengan judul peran keterlibatan orang tua dalam proses membaca pada anak menunjukkan bahwa orang tua yang terlibat di lingkungan keluarga dalam proses belajar anak khususnya dalam membaca mempengaruhi motivasi membaca anak dan kemampuan membaca yang berkaitan dengan minat. Hasil penelitian ini telah membuktikan bahwa persepsi keterlibatan orangtua dalam pendidikan berhubungan signifikan dengan minat baca siswa. Sumbangan efektif perspesi keterlibatan orangtua dalam pendidikan terhadap minat baca siswa adalah sebesar 46,1\% sedangkan sisanya sebesar 53,9\% dipengaruhi oleh variabel lain yang tidak diteliti.

\section{Kesimpulan}

Berdasarkan hasil analisis data dan pembahasan terhadap hasil penelitian, maka dapat diambil kesimpulan sebagai berikut:

1. Hipotesis yang diajukan pada penelitian ini dinyatakan diterima yaitu ada hubungan positif antara persepsi keterlibatan orangtua dalam pendidikan dengan minat baca. Semakin positif persepsi keterlibatan orangtua dalam pendidikan maka semakin tinggi pula minat baca. Sebaliknya, semakin negatif persepsi keterlibatan orangtua dalam pendidikan maka semakin rendah minat baca. Sumbangan efektif persepsi keterlibatan orangtua dalam pendidikan dengan minat baca adalah $46,1,6 \%$ sedangkan 53,9\% ditentukan oleh variabel lain tidak diukur dalam penelitian ini.

2. Hasil penelitian ini menunjukkan bahwa minat baca siswa berada pada kategori sedang sebanyak $80,6 \%$, dan siswa memiliki persepsi keterlibatan orangtua yang tinggi sebanyak $51,6 \%$.

\section{Saran}

1. Sekolah diharapkan dapat menumbuhkan dan meningkatkan minat baca siswa membiasakan siswa-siswi melalui kegiatan-kegiatan seperti lomba membaca buku, lomba mendongeng ataupun kegiatan-kegiatan untuk membiasakan perilaku membaca sejak dini.

2. Hal penelitian menyatakan bahwa Persepsi keterlibatan orangtua dengan minat baca berkorelasi positif dan signifikan dengan minat baca. Bagi orang tua untuk tetap mempertahankan terlibatnya dalam kegiatan membaca bersama anak dengan terlibat di rumah, terlibat di kegiatan sekolah dan mempersipakan masa depan anak dengan mensosialisasikan informasi tentang pengetahuan-pengetahuan seputar belajar dan bersama-sama dengan anak mempersipakan diri lewat startegi belajar untuk kesuskesan akademik. Orangtua bisa terlibat lebih serius di rumah 
seperti mendampingi anak belajar, mengerjakan PR maupun komunikasi yang baik dengan anak saat belajar. Untuk aktivitas disekolah orangtua bisa mengambil peran untuk terlibat misalnya sebagai nara sumber dalam topik terkait dengan bidang kepakaran orang tua ataupun terlibat dalam kegiatan Family Day dimana semua orang tua secara sukarela hadir mendukung kegiatan Family Day di sekolah.

\section{Daftar Pustaka}

Arumdini, S., Winoto, Y., \& Anwar, R. K. (2016). Hubungan Antara Pola Asuh Orang Tua Dengan Minat Baca Anak. Jurnal Kajian Informasi E Perpustakaan, 4(2), 171-178.

Azwar, S. (2017). Dasar-dasar Psikometrika. Yogyakarta : Pustaka Pelajar

Bandura, A. (2011). Social Learning Theory. Prentice-Hall.

Central Connecticut State University. (2016). World's Most Literate Nations ranked. Diunduh dari https://webcapp.ccsu.edu/?news=1767\&data/ tanggal 13 maret 2019

Dalman, H. (2013). Ketrampilan Membaca. Jakarta : PT. Raja Grafindo Persada.

Epstein, J. (2011). School, family, and community partnerships: preparing educators and improving schools. Boulder, CO: Westview Press.

Fakhriyah, D.S. (2018). Peran Persepsi Keterlibatan Ayah dan Keterlibatan Ibu serta Konsep Diri Membaca terhadap Minat Baca Siswa Sekolah Dasar. (Tesis tidak dipublikasikan). Fakultas Psikologi Universitas Gadjah Mada, Yogyakarta.

Hill, N. E., \& Tyson, D. F. (2009). Parental involvement in middle school: a meta-analytic assessment of the strategies that promote achievement. Developmental psychology, 45(3), 740 - 750,

Hornby, G. (2011). Parental Involvement in Childhood Education: Building Effective SchoolFamily Partnerships. Springer Science \& Business Media.

Hurlock, E.B. (2013). Perkembangan anak. Jilid 2. Jakarta : Erlangga.

Kementerian Pendidikan dan Kebudayaan Republik Indonesia (2018). Seri pendidikan orang tua: Menumbuhkan minat baca anak [Parental education series - Fostering children's interest in reading]. Jakarta: Direktorat Pembinaan Pendidikan Keluarga.

Kimathi, H. K. (2014). Parental Involvement in Primary Standard three Pupils' Reading at Home in Igembe South Constituency, Meru County, Kenya. (Unpublished Masters Thesis), Kenyatta University. 
Mansyur, U. (2018). Korelasi Minat Baca dengan Kemampuan Menulis Karya Tulis Ilmiah Mahasiswa Pendidikan Bahasa Indonesia UMI. Multilingual: Jurnal Kebahasaan dan Kesastraan, 17(1), 11-22.

Nursalina, A. I., \& Budiningsih, T. E. (2014). Hubungan Motivasi Berprestasi dengan Minat Membaca Pada Anak. Educational Psychology Journal, 3(1), 1-7

Rachman, M. A., Rachman, Y. B., \& Rachmawati, Y. M. (2018). Minat Baca Siswa Sekolah Dasar di Depok: Studi Kasus di SDN Anyelir 1 Depok Jaya. Jurnal Ilmu Informasi, Perpustakaan, dan Kearsipan, 19(2).

Rahmawati, N., \& Arnomo, I. (2016). Peran Aktif Ibu dalam Menumbuhkan Minat Baca pada Anak (Studi Deskriptif pada Pekerja Wanita di Universitas Hang Tuah Surabaya). Humaniora, Volume 13 (2), 78-95.

Rahmi, R. (2019). Parental Involvement To Increase Children's Reading Interest For Preschool Children's Character Development. In International Conference on Early Childhood Education (pp. 435-444).

Robinson, K., \& Harris, A. L. (2014). The broken compass: Parental Involvement with Childern's Education. London : Harvard University Press.

Schunk, D.H . (2010) . Motivation in Education: Theory, Research, and Applications. Third Edition. New Jersey: Pearson Education

Shohibah, R. (2017). Peran Orang Tua dalam Mengembangkan Budaya Literasi pada Anak Usia Sekolah Dasar. The 1st International Conference on Language, Literature and Teaching.

Sudarsana, U. (2014). Pembinaan Minat Baca. Jakarta: Gramedia.

Surya, M. (2013). Psikologi Guru Konsep dan Aplikasi. Bandung: Alfabeta.

Susilowati, S. (2016). Meningkatkan Kebiasaan Membaca Buku Informasi pada Anak Sekolah Dasar. Jurnal Ilmiah Guru Caraka Olah Pikir Edukatif, 20(1), 1-8.

Yaumi, M. (2014). Pendidikan karakter: Landasan, pilar dan implementasi [Character education: Rationales, pillars, and implementation]. Jakarta: Prenadamedia Group. 